\title{
Climate change effects on livestock in the Northeast US and strategies for adaptation
}

\author{
A. N. Hristov ${ }^{1}$ A. T. Degaetano ${ }^{2}$ - C. A. $\operatorname{Rotz}^{3} \cdot$ \\ E. Hoberg ${ }^{4}$ R. H. Skinner ${ }^{3}$ T. Felix ${ }^{1}$ - H. Li $^{5}$. \\ P. H. Patterson ${ }^{1}$ - G. Roth $^{1}$ - M. Hall ${ }^{1}$ - T. L. Ott ${ }^{1}$. \\ L. H. Baumgard ${ }^{6}$ - W. Staniar ${ }^{1}$ - R. M. Hulet ${ }^{1}$. \\ C. J. Dell ${ }^{3}$ - A. F. Brito ${ }^{7}$ - D. Y. Hollinger ${ }^{8}$
}

Received: 4 November 2016 / Accepted: 28 June 2017 / Published online: 17 July 2017

(C) The Author(s) 2017. This article is an open access publication

\begin{abstract}
The livestock industries are a major contributor to the economy of the northeastern United States. Climate models predict increased average maximum temperatures, days with temperatures exceeding $25{ }^{\circ} \mathrm{C}$, and higher annual precipitation in the Northeast. These environmental changes combined with increased atmospheric $\mathrm{CO}_{2}$ concentration are expected to either increase or decrease forage productivity depending on the crop, and may decrease protein content and forage digestibility. Winter damage to sensitive forage species may also increase. Predicted temperature increases are expected to reduce fertility in dairy cattle and heat stress-induced inflammation may limit energy available for productive functions.
\end{abstract}

This article is part of a Special Issue on "Vulnerability Assessment of US Agriculture and Forests developed by the USDA Climate Hubs" edited by Jerry L. Hatfield, Rachel Steele, Beatrice van Horne, and William Gould

Electronic supplementary material The online version of this article (doi:10.1007/s10584-017-2023-z) contains supplementary material, which is available to authorized users.

\section{A. N. Hristov}

anh13@psu.edu

1 The Pennsylvania State University, University Park, PA, USA

2 Cornell University, Ithaca, NY, USA

3 Pasture Systems and Watershed Management Research Unit, USDA-ARS, University Park, PA, USA

4 USDA, Agricultural Research Service, Animal Parasitic Diseases Laboratory, Northeastern Area, Beltsville Agricultural Research Center, Beltsville, MD, USA

5 University of Delaware, Newark, NJ, USA

6 Iowa State University, Ames, IA, USA

7 University of New Hampshire, Durham, NC, USA

8 USDA Forest Service, Northern Research Station, Durham, NC, USA 
Additional loss in milk production due to decreased feed intake is estimated to be up to $1 \%$ of the projected annual milk production through 2100 . The effects of climate change on the beef industry in the Northeast are expected to be minimal. Broiler production in the region may benefit from warmer winter and summer temperatures, but future housing will require greater insulation and ventilation fan capacity. Providing adequate housing and ventilation to offset climate changes will also be important for the layer industry and will likely increase the price of eggs. Climate change is expected to have an economic impact on the horse industry in the region through additional management of land and forage resources, building of shelters, and heat abatement at equine events. Increased temperatures and more intense storms will increase nutrient losses and gaseous emissions from animal manure. Uncertainties about how host animals, pathogens, and disease vectors will respond to climate change highlight the need for continued animal health monitoring.

\section{Economic impact of the livestock industries in the Northeast}

Dairy production is a major contributor to the agricultural economy of the northeastern US. Total milk and dairy product sales in the region exceeded \$7.5 billion in 2014 (USDA-ERS 2016). As the top agricultural commodity of the Northeast (NE), sales of dairy products represented $32 \%$ of all farm receipts. Beef animals in the NE represent $3.7 \%$ of the national inventory, but just $2 \%$ of the national cattle and calf farm receipts, at $\$ 1.69$ billion in 2014 (USDA-ERS 2016). Poultry production in the NE includes broiler chicken, egg, and turkey operations, providing $\$ 4.50$ billion in cash receipts in 2015 (NASS 2015). Poultry and egg production in the region represents $9.4 \%$ of the total value produced in the USA. The NE horse industry is an important segment of animal agriculture. Using a conservative estimate of $\$ 2000$ to $\$ 6000 /$ horse, the total value of horses in the NE is between $\$ 1.4$ and $\$ 4.3$ billion. The GDP impact of the region's horse industry is estimated at $\$ 7.5$ billion, which is about $7.4 \%$ of the national impact of $\$ 101$ billion in 2005 (AHCF 2005). Sheep, goats, and pigs are additional livestock sectors in the NE. The region's sheep sales, including lambs, totaled $\$ 34.5$ million in 2012 and goat sales were estimated at $\$ 10.8$ million (NASS 2012). The swine industry had a $\$ 362.5$ million production value in the NE in 2013 .

\section{Climate trends and projections for the Northeast-a summary}

Kunkel et al. (2013) highlight a number of significant historical climate trends that characterize the NE. These include the following:

- More extremely warm nights (minimum temperature $>21{ }^{\circ} \mathrm{C}$ )

- Fewer extremely cold and cold nights $\left(<-18^{\circ} \mathrm{C}\right.$ and $\left.<0{ }^{\circ} \mathrm{C}\right)$;

- Warmer average winter and summer temperature;

- More days with heavy rain (generally $>5.0$ to $7.6 \mathrm{~cm}$ events);

- Higher annual precipitation.

New, down-scaled climate model projections, described in the Supplementary Material of this article, highlight the expected evolution of these trends in the NE through the twenty-first century. Temperature, the climate factor that will most directly impact livestock and poultry in 
the NE, will continue to increase (Figs. S1-4). Although an increase in the occurrence of extremely warm maximum temperatures has not yet been observed in the NE historical record (Kunkel et al. 2013), extreme maximum temperatures are projected to increase (Thibeault and Seth 2014) through the twenty-first century (Fig. S5). However, changes in relative humidity, which can exacerbate summer heat stress, are expected to be minimal through the current century (Fig. S6). Cold winter extremes are expected to decrease (Fig. S7). Increased temperatures will alter the growing season timing and length (Fig. S9) and increase growing degree day (GDD) accumulation (Fig. S8).

Factors related to increased precipitation amount and intensity (Figs. S10-14) will also influence the livestock industries indirectly by impacting the quantity and quality of feed (and pasture conditions), manure management, and animal health. As the largest increases in precipitation are projected to occur in the winter and spring (Sun et al. 2015), early season field working conditions may be delayed by saturated soil conditions.

\section{Climate change impact on soil, pasture, and forage production and quality}

Potential changes in the productivity and quality of forage crops as a result of climate change are summarized in Supplementary Material Table S2. Increasing atmospheric $\mathrm{CO}_{2}$ by itself could increase cool-season pasture growth and perennial warm-season grass growth during drought years. Interactions with changes in temperature and precipitation will impact the response to elevated $\mathrm{CO}_{2}$. The duration of vegetative growth for perennial pastures is expected to increase due both to warmer temperatures and increased atmospheric $\mathrm{CO}_{2}$, leading to increased herbage availability early in the year. Increased growth due to increasing $\mathrm{CO}_{2}$ also tends to reduce forage $\mathrm{N}$ concentration which could have positive or negative effects on forage quality depending on the maturity of plants when harvested.

Models predict increased precipitation from late autumn through early summer with the greatest increase from February to April (see Supplementary Material). This will lead to wetter soils during spring and may decrease the number of suitable days for agricultural operations and restrict animal access to pastures. Temperature and precipitation patterns may exaggerate the already existing bimodal nature of cool-season growth, enhancing spring and fall growth while reducing growth in the summer. Reduced snow cover could increase exposure to extremely cold temperatures by reducing the insulating effect of snow, resulting in greater winterkill even when average winter temperatures are increasing. The greatest risk will be in the northernmost and snowiest regions of the NE (Maine, Vermont, New Hampshire, and northern New York), but changes in freeze/thaw patterns are likely to impact plant growth throughout the region.

Impacts of climate change on the predominant annual forages such as whole-crop corn and small grains should generally be positive but may require some adaptation by growers (Challinor et al. 2014). Elevated air temperature should increase the growing season and permit longer season hybrids and later planting to accommodate double cropping with small grains in more regions. Increased late winter and spring precipitation could result in planting delays on some soils but these impacts could be offset by longer growing seasons and perhaps mitigated by more efficient planting techniques. On well-drained soils, earlier planting would be more likely (Rotz et al. 2016). Less frequent but more intense precipitation could result in more midseason drought episodes and crop damage. These impacts would likely be more severe on corn grain yields than corn silage yields. Elevated $\mathrm{CO}_{2}$ levels should also result in 
increased corn silage yields. In areas with shallow soils where drought impacts may be severe, or in areas with wet soils where planting could be delayed until late spring, there could be some substitution of forage sorghum or sorghum sudan for corn silage as these crops are more adapted to later planting and have higher levels of drought tolerance (Getachew et al. 2016).

Forage yields of small grain crops should increase due to elevated atmospheric $\mathrm{CO}_{2}$ levels and air temperatures, which should increase the potential for fall and spring tillering (tillers are secondary shoots that develop on small grain plants that also can form heads in addition to the main shoot). More cold-sensitive winter crops such as winter barley may suffer more winterkill in some regions such as central PA and central NY due to decreased snow cover and lower soil temperatures. More winter hardy species like cereal rye and triticale should not be affected.

Impacts of climate change on crop yields by the end of the century were estimated by Rotz et al. (2016) for a central NY dairy farm following a continuing high greenhouse gas (GHG) emission scenario and the associated increase in atmospheric $\mathrm{CO}_{2}$ concentration. Assuming that management is adapted, yields of alfalfa, corn silage, wheat grain, and wheat straw were projected to increase by $12,22,5$, and $32 \%$, respectively. Annual yield of orchard grass hay were projected to decline by $17 \%$, and drought and hot temperatures during critical stages of development to decrease corn grain yield by $7 \%$.

While climate change can impact soil $\mathrm{C}$ balance in various ways, adoption of practices that maintain and/or build soil organic matter can improve system resilience to climate change. Not only is organic matter a carbon sink, but it is also the primary manageable factor controlling soil health. Building soil organic matter can lessen the impact of extended drought by increasing plant available water holding capacity (Hudson 1994). Greater organic matter also improves soil structure, allowing greater water infiltration and erosion control following extreme precipitation events (Franzluebbers 2002).

Pasture and perennial forage production generally maximizes soil organic matter accumulation, whereas corn silage production often leads to depletion of organic matter, especially if soils are tilled. However, no-till planting, manure application, and/or winter cover crops can help maintain organic matter levels under corn silage (Dell et al. 2008). A trend toward warmer temperatures may allow better success with no-till and cover crop establishment in northern portions of the region.

Manure management policies may also play a positive role. Wider distribution of manure, to avoid excess accumulation of soil phosphorus in high livestock concentration areas, can increase overall carbon sequestration and provide soil health benefits to more crop- and pasture-land. Since soils have a saturation point for organic matter accumulation (Six et al. 2002), continued application to the same soil tends to lead to greater loss of carbon, while application of manure to soils below the organic matter saturation point leads to the greatest sequestration.

\section{Climate change impact on livestock}

\subsection{General issues}

Animals have optimal temperature ranges for growth and comfort known as the thermo-neutral zone (TNZ) that depend on the species, animal age and physiological state, relative humidity, and other factors. Within the TNZ, an animal has highest productivity and most efficient conversion of feed. If temperatures are too cold, metabolism may increase, reducing growth. 
Low temperatures will result in increased feed intake to meet increased maintenance energy needs (NRC 2016). Above the TNZ, heat stress may lead to decreased feed intake and production (milk, eggs), increased mortality, or decreased reproduction. With climate change, the issue is how temperatures at a particular location change relative to different species TNZ. The NE is fortunate in that there is presently less animal heat stress than in most other regions of the country (St-Pierre et al. 2003).

\subsection{Dairy cattle}

Warmer and wetter conditions in the NE are likely to increase problems associated with heat stress in dairy cattle. Increased temperatures can affect dairy production by (1) effects on feed production and feed nutritive value, (2) effect on feed intake, and (3) effects on energy requirements, animal health, and reproductive efficiency. Feed dry matter intake (DMI) is the main determinant of milk production in lactating dairy cows (Hristov et al. 2004). Heat stressinduced reduction in nutrient intake is a major cause of reduced production and accounts for approximately $50 \%$ of the decrease in milk yield (Baumgard and Rhoads 2013). A similar relationship exists between heat stress and animal growth. If climate change affects feed DMI, productivity of dairy cows is also expected to change. Dry matter intake will increase or decrease depending on deviations in ambient temperature from the TNZ, which for dairy (and beef) cattle ranges from 5 to $25^{\circ} \mathrm{C}$ (McDowell 1972; NRC 2016). For example, DMI is likely to remain stable between 10 and $20{ }^{\circ} \mathrm{C}$, will increase below $10{ }^{\circ} \mathrm{C}$, and will start decreasing slowly above $20{ }^{\circ} \mathrm{C}$ and more rapidly above 28 to $30{ }^{\circ} \mathrm{C}$ (NRC 1981). Animal energy requirements for maintenance may also increase with heat stress, although data are not conclusive (NRC 2001). Water consumption will increase with increasing ambient temperature up to about $35^{\circ} \mathrm{C}$, but will then decline due to decreasing DMI.

Humidity is an important factor of heat stress in cattle and a temperature-humidity index (THI) is used to estimate risk of heat stress. Using THI as an indicator of heat stress, the impact of increased temperatures on DMI and milk production in the NE can be projected (see Supplementary Material for details). Under the Representative Concentration Pathway (RCP) 8.5 scenario (i.e., high-emissions scenario), the additional loss in milk production due to increased temperature, heat stress, and thus, decreased DMI are expected to be about $0.40 \%$ of the projected annual milk production in 2050 and $1.02 \%$ in 2100 . This would represent an additional economic loss to the NE dairy industry of $\$ 49.1$ and $\$ 125.8$ million/year, respectively. Depending on local climate, some areas will be affected less and some more (see Supplementary Material for a case study of Lancaster County, PA). Overall, however, the impact of decreased DMI due to climate change on the NE dairy industry is projected to be relatively small. The potential impact of climate change on other productive traits in dairy cattle, such as milk quality, as well as heat abatement practices and GHG mitigation options, are further discussed in Supplementary Material.

The physiological responses to heat stress in dairy cattle include altered hormonal status, reduction in rumination and nutrient absorption, suboptimal immune function, and increased maintenance requirements resulting in a net decrease in nutrient/energy available for growth, reproduction, and lactation (Baumgard and Rhoads 2013; De Rensis et al. 2015).

Heat stress reduces fertility by affecting the ovaries, uterus, and the hormones regulating their function (De Rensis et al. 2015). Furthermore, heat stress increases embryo mortality and results in birth of smaller and less vigorous calves. Heat stress causes longer estrous cycles and a shorter duration of estrus. Dairy cattle can handle extremes of heat and cold for short periods 
of time, but efficient production requires that cows stay within their TNZ (De Rensis et al. 2015). Cows in the Southeast (SE) and Southwest US exhibit reduced fertility that can be mitigated by artificial cooling (fans, sprinklers, shade, etc.). In the NE, many dairy facilities will struggle with the capital investment to improve heat abatement. Furthermore, grazing dairies may be disproportionally affected if cows are spending many hours per day above their TNZ on pasture. The most extreme predicted temperature increases from current models $\left(6.5^{\circ} \mathrm{C}\right.$; see Supplementary Material) are expected to reduce fertility in dairy cattle in the NE. The impact of this can be evaluated by comparing pregnancy rates in the NE with those in the SE. A reduction in pregnancy rates from the current $20 \%$ in the NE to $15 \%$ (average of SE states; Dairy Records Management System, http:/www.drms.org/ accessed August 2016) would result in $>\$ 50$ million in lost income per year (De Vries 2006; Cabrera 2014). This loss includes losses due to lower milk production, increased culling of non-pregnant cows, and increased costs of repeat inseminations. Heat-stressed cows exhibit lower fertility, which will result in a higher percentage of cows failing to conceive during the economically desirable window between 110 and 130 days after calving. Cows that do not conceive by 175 days after calving become candidates for removal from the herd due to lowered milk production. However, to minimize the impact of warmer temperatures, dairy producers will likely respond by adopting additional heat abatement strategies and hormonal synchronization protocols. Furthermore, producers are using genetic selection strategies that include greater emphasis on fertility traits and disease resistance (Boichard and Brochard 2012) and will have opportunities to select for resistance to heat stress as well (Dikmen et al. 2015). Inclusion of these traits into selection indexes will likely result in reduced genetic gain in production traits commensurate with their weighting in the selection index. Thus, it is likely that smaller or more financially leveraged dairies will exit the industry at a greater rate, which would accelerate consolidation of the industry toward fewer and larger dairy operations.

Heat-stressed cows lose body weight and exhibit altered nutrient utilization (Baumgard and Rhoads 2013). This creates a nutrient trafficking problem that reduces milk production. Problems associated with heat stress appear to originate in the intestine and result in movement of intestinal bacteria or bacterial products into the blood stream. During heat stress, blood flow is diverted from the viscera to the periphery in an attempt to dissipate heat leading to intestinal hypoxia. This contributes to a breakdown in the gut lining that ultimately reduces intestinal barrier function (Baumgard and Rhoads 2013). This induces systemic inflammation and accounts for some of the altered metabolism describe above (Baumgard and Rhoads 2013). Breakdown of barrier function will result in reduced digestion and absorption of feed nutrients and result in reduced feed efficiency. Further, mounting an effective immune response to infection is energetically expensive and, when not properly regulated, can result in permanent tissue damage or animal death. Therefore, heat stress-induced inflammation limits energy available for productive functions (growth, reproduction, and milk production; Baumgard and Rhoads 2013). Overall, predicted changes in climate will likely result in reduced production efficiency in dairy cattle, stemming from reduced feed intake, reduced feed efficiency, and increased incidence of metabolic stress. This will result in increased incidence of diseases and lowered fertility and, as indicated earlier, will likely accelerate consolidation of dairy cows onto fewer and larger farms.

\subsection{Poultry}

Modern broiler breeds are selected for high feed efficiency and fast growth rate over a short growth cycle under a controlled environment, which makes them more vulnerable to climate 
change. Rapid growth requires that the housing system provides an optimum thermal environment year round to protect birds from extreme weather. This requires heating, cooling, and ventilation systems that consume energy (Bell and Weaver 2002). The challenges posed by climate change on broiler production are twofold: (1) increased energy cost to maintain an optimum environment, and (2) potential impaired productivity from heat stress. Production performance suffers when the producer tries to conserve energy by reducing environment abatement (Reece et al. 1969). Intense and prolonged heat stress causes reduced production performance and greater mortality in broilers. Tunnel ventilation is a standard practice to alleviate heat stress using a wind-chill effect (Lott et al. 1998). Projections in the NE (Thibeault and Seth 2014) for warmer winter and summer temperatures and fewer extreme cold nights would benefit broiler production by reducing fuel usage and disease challenges through better ventilation and an improved housing environment. Fuel usage decreases by $3.4 \%$ for every $1{ }^{\circ} \mathrm{C}$ of ambient temperature increment while electricity usage for ventilation remains relatively steady (Liang et al. 2009). Future housing will most likely require greater insulation and greater ventilation fan capacity to offset warmer temperatures. Some of the added cost (i.e., increased ventilation and cooling) will be offset by energy savings during warmer winters.

There has been a steadily increasing trend over the past few years for antibiotic free (ABF), organic, and all natural meat birds in the NE. Environmental control and management is more stringent for $\mathrm{ABF}$ and organic birds, and this requires more floor space, better ventilation, cleaner air, and drier litter.

Climate change trends also align with the needs of pullets and laying hens for efficient feed consumption and feed conversion. Warming ambient temperatures will reduce the cost of fuel needed to heat the brooding barns and maintain desirable temperatures. Heat stress reduces pullet growth, egg production, and the quality of eggs. Heat stress also reduces shell thickness $(-1.2 \%)$ leading to a greater percentage of cracked or broken eggs and economic loss (Ebeid et al. 2012).

Housing type and welfare standards are having a major impact on the egg industry creating a migration to lower density cages, cage-free settings, and/or outdoor access. This change is creating challenges in environmental control. Lower density reduces the heat load in the summer, but also reduces heat production in the winter. Outdoor access portals in the barn complicates ventilation by short circuiting efficient use of inlets, fans, and the rest of the ventilation system to the detriment of the bird. Overall, providing adequate housing and ventilation equipment to offset climate changes will increase the price of eggs as these costs are already a significant cost of production.

Turkey production has been steadily increasing in the NE over the past few years, mostly in the niche market of ABF, organic, heritage, and all natural (no meat or meat product in diets) birds. Similar to chicken, the greatest effect of climate change on the rearing of commercial turkeys will be on feed production and availability and a rise in energy costs of, conservatively, around $15 \%$ by 2100 . However, the ability of producers to rear and grow birds may be enhanced by housing systems with better environmental control, resulting in a continual rise in the production of turkeys in the NE. Increased marketing to the higher margin areas of ABF, organic, heritage, and all natural reared poultry is likely to continue.

\subsection{Beef cattle}

Beef producers adapt to forage production changes with "flexible" stocking rates. When conditions are good (i.e., excess grass for the cow herd), producers harvest hay or buy calves to graze. However, even in the best pasture conditions, it is suggested that pasture cows be 
limited to 20 to $60 \%$ of the total grazing capacity and the remaining 40 to $80 \%$ of pasture be used for purchased calves or hay production. This strategy allows producers to avoid liquidating cows when pasture supply is limited by simply not purchasing the stockers that year (Lyons and Machen 2001). Increasing forage availability, discussed above, may increase grazing days in the $\mathrm{NE}$, increasing the relevance of the cattle industry. Grazing beef cattle in the NE often begins in April and can occur through December, when ice and snow typically limit grazing.

Projected temperature changes, hotter nights and fewer cold days, may reduce maintenance costs for the cattle industry. Maintenance requirements of beef cows increase $33 \%$ when temperatures decrease from 0 to $-23{ }^{\circ} \mathrm{C}$; and a wet, matted hair coat increases maintenance even more, $74 \%$ increase in maintenance requirements, at the same temperature decrease (NRC 2016). Despite this, voluntary feed intake does not vary much for beef cattle between 8 and $-16{ }^{\circ} \mathrm{C}$ (Stanton 1995) because beef cattle modify behavior (move in to the sun, group together, seek shelter, etc.) to mitigate effects (NRC 2016). With the projected rise in temperature discussed throughout this paper, beef cattle will have fewer maintenance costs due to cold temperatures in the NE through the winter months.

However, similar to other livestock species, beef cattle responses to heat stress include increased maintenance nutrient requirements and reduced intake and growth (Johnson et al. 2015). Recommendations for beef cattle (NRC 2016) are to increase maintenance requirements estimates by approximately $1 \%$ for every $1{ }^{\circ} \mathrm{C}$ of ambient temperature above $20{ }^{\circ} \mathrm{C}$. Reductions in intake, and subsequently productivity, may be more dramatic in cattle suffering heat stress than those suffering cold stress (NRC 2016). However, St-Pierre et al. (2003) suggested the magnitude of beef productivity loss caused by changing temperature is "relatively small" in relation to productivity losses in all other animal sectors because beef cattle have lower metabolic rates (than, e.g., dairy cattle), large ranges in comfortable ambient temperature, and the bulk of production (calving) occurs in milder spring months (St-Pierre et al. 2003). Feedlot cattle suffering heat stress are more likely to grade as dark cutters, discounting meat value (Mitlöhner et al. 2002). Cooling technologies, to keep cattle comfortable and eating (shade, sprinkler, fans, etc.), have been investigated for large Midwestern feedlots. However, use of such technologies may not completely alleviate productivity losses, due to chronic effects on post-absorptive metabolism (Baumgard and Rhoads 2013), thus not justifying the expense in the NE (St-Pierre et al. 2003). Economic losses from climate change estimated for the NE in 2003 were $<0.5 \%$ of all beef cow losses in the USA, and losses for feedlot cattle were too small to calculate (St-Pierre et al. 2003). Based upon average temperature increases ranging from 3.9 to $6.5^{\circ} \mathrm{C}$, impact of climate change on beef cattle and beef production losses in the NE should be minimal.

Increased moisture in the region may have an impact on beef cattle grazing operations. Housing is not generally considered necessary for grazing cattle; however, increased winter precipitation may reduce pasture stocking rates and increase housing needs for grazing beef (Nienaber and Hahn 2007).

\subsection{Horses}

Climate change will impact the NE horse industry through changes in the yields and timing of availability of cool and warm season forages, soil health and runoff, need for shelter in pastures, and heat stress abatement at equine athletic events. Over $90 \%$ of horses in the NE are offered access to pasture throughout the day (APHIS 1998). Climate change impacts may include longer growing and grazing seasons, lower plant digestibility, increased periods of summer slump in 
forage production, and a combination of positive and negative impacts due to changing seasonal forage population dynamics. Soil erosion and surface water runoff in horse paddocks may be greater with increased precipitation, due to horses' large size, hoof anatomy, and time grazing (Bott et al. 2013). Predicted changes will require management modifications, such as rotational grazing, incorporation of warm season grasses, and small non-grazable paddocks that require little maintenance, particularly during times of heavy precipitation.

Horses are adapted to a TNZ from -15 to $25^{\circ} \mathrm{C}$ (NRC 2007), emphasizing adaptation to cool temperatures and metabolic burden of temperatures above $25^{\circ} \mathrm{C}$. The summer average and maximum temperature in the NE in 2015 was 19.8 and $25.7^{\circ} \mathrm{C}$, respectively (NRCC 2016). Based on a maximum (RCP 8.5) $6.5^{\circ} \mathrm{C}$ increase by 2100 , the summer average and maximum temperatures would be 24.3 and $30.8{ }^{\circ} \mathrm{C}$. Under these conditions, recreational horses will have a greater need for shelter from sun and precipitation (Holcomb et al. 2015; Snoeks et al. 2015), and equine athletic events will need to evaluate the risk of heat stress and incorporate heat abatement systems.

Overall, predicted climate changes for the NE region are likely to have an economic impact on the horse industry through the additional management of land and forage resources, building of shelters, and climate monitoring and heat abatement at equine events. The horse industry is composed of a great diversity of operations making any realistic estimate of an economic impact due to climate change beyond the scope of this document.

\section{Climate change impact on livestock manure management}

Manure handling and nutrient use is an important component of livestock production. Manure contains valuable nutrients for plant growth, but large losses occur as the manure is recycled from the animals to cropland. For the environment, the major nutrients of concern are nitrogen, phosphorus, and carbon. Losses of these nutrients contribute to environmental issues including climate change, eutrophication of surface waters, ground water contamination, acid rain, and small particulate matter emissions. Climate affects nutrient losses from manure in many ways, and projected changes will exacerbate these losses (Rotz et al. 2016).

Nitrogen in manure is the most difficult nutrient to manage. Manure nitrogen transforms and is lost through several pathways including volatilization as ammonia, leaching and runoff as nitrate, and nitrification and denitrification processes producing nitrogen oxides (Rotz 2004). Reducing losses from one source often leads to greater losses through other pathways. Ammonia volatilization is often the pathway of greatest nitrogen loss, and this emission is highly sensitive to temperature (Rotz et al. 2014). Using current manure handling methods, projected climate changes in the NE may increase ammonia losses $20 \%$ by midcentury and up to $39 \%$ by 2100 (Rotz et al. 2016). Leaching of nitrates to groundwater after manure is applied to cropland is often the second largest pathway of loss, and projected climate change may have offsetting effects on this loss. Increased precipitation and storm intensity can increase leaching loss, but the longer growing season and increased temperatures will increase plant uptake and evapotranspiration thus reducing the potential for leaching. Nitrification and denitrification processes occur in environments such as the crust that often forms on the surface of manure storages and manure in bedded pack barns or on open lots. After manure is incorporated into soil, these processes continue. With wetter and warmer conditions, nitrous oxide emissions are projected to increase about $12 \%$ by midcentury and $24 \%$ by 2100 on NE dairy farms (Rotz et al. 2016). 
Phosphorus is primarily lost through runoff to surface waters. Both phosphorus and nitrogen runoff are relatively small, but they remain a major contributor to eutrophication of NE waters including the Chesapeake Bay, Lake Champlain, and the Delaware River. Increases in precipitation and storm intensity are projected to increase these losses as much as $40 \%$ by midcentury and $87 \%$ by 2100 , if further steps in mitigation are not taken (Rotz et al. 2016).

Carbon is lost from manure as methane and $\mathrm{CO}_{2}$ where only methane is considered an environmental concern. Methane is emitted during all phases of manure handling, but the major source is long-term storage. The microbial decomposition of manure-producing methane is sensitive to temperature, so projected climate changes will increase emissions by about $4 \%$ by midcentury and $8 \%$ by 2100 (Rotz et al. 2016).

Implementation of mitigation practices to reduce these losses is critical to maintain sustainable livestock production in the NE, and the need for mitigation is increasing with climate change. Mitigation must start with the feeding of animals. More optimal feeding of nutrients reduces the excretion of those nutrients, and with lower nutrient concentrations in the manure, all pathways of loss are reduced. For nitrogen in particular, the excess fed (i.e., protein) is primarily excreted in urine where it is easily transformed and volatilized. Barn floor designs that allow separation of urine and feces can reduce ammonia emissions, which may become useful in dairy and swine production.

For long-term manure storage, covers are effective for reducing gaseous emissions and the resulting odor. By sealing the cover and using a flare to convert methane to $\mathrm{CO}_{2}$ and other devices to remove nitrogen compounds, greater reductions and perhaps near elimination of storage emissions can be obtained. Anaerobic digesters can be used to enhance methane production, where this biogas is used to heat water and generate electricity. Extraction of the carbon from the manure reduces other downstream emissions, and the reduction in purchased gas and electricity provides other off-farm environmental benefits.

Surface application of manure can lead to emissions of ammonia and runoff of nitrogen and phosphorus. By injecting the manure below the soil surface, ammonia emission can be reduced by $80 \%$ and runoff losses by $50 \%$ (Rotz et al. 2011). Timely and appropriate application of the manure is important though to allow plant uptake of the additional nitrogen applied or that nitrogen will be lost through other pathways as nitrates and nitrous oxide.

Applying the large amounts of manure created by livestock often requires many days of suitable weather. Projected increases in precipitation, particularly in the spring, may reduce the time available for field application of manure. On the other hand, warmer temperatures and a longer growing season may allow more time for manure handling, tillage, and planting of crops. Thus, the net effect of climate change on these operations may be minor or difficult to predict.

Modified cropping systems can also improve utilization of the manure nutrients and reduce ammonia and GHG emissions. The use of winter cover crops and double crops can maintain ground cover for most of the year increasing crop uptake and reducing leaching and surface runoff. With projected increases in temperature, these cropping practices may become more practical throughout the NE. Further discussion on GHG mitigation from manure management can be found in the Supplementary Material.

\section{Climate change impact on emerging pathogens and disease}

A diverse spectrum of pathogens and disease conditions may be influenced by climate change over the coming century (see Supplementary Material). Production livestock practices may 
serve as primary buffers that limit the potential impact of a direct disease-climate interaction. For example, poultry and swine confinement systems can dramatically reduce the levels of environmental exposure and potential interactions with arthropod vectors and endemic wildlife species such as migratory waterfowl involved in circulation of avian influenza and other viruses. Confinement, however, is not a panacea as poultry, swine, and young ruminants held in moist warm barns may be more susceptible to infections and outbreaks of viral and bacterial pathogens and enteric coccidian parasites. In contrast, animals raised in free-range settings, that allow contact on pasture with other ungulates such as white-tailed deer, or with exposure to directly transmitted organisms, or potential blood-feeding arthropod vectors, will encounter a broader array of pathogens.

Changes in the distribution of pathogens can be a signature for climate change, especially at the livestock-wildlife interface (e.g., Hoberg et al. 2008; Miller et al. 2013). Climate warming may create broadening ecotones (areas of contact) and interfaces for exchange of pathogens among domestic animals, wildlife, and people. The potential costs for animal and human health of these changes may exceed several billions of dollars (e.g., Miller et al. 2013), although detailed and fine-scale estimates of economic losses at regional have yet to be developed. Under a regime of accelerating change, however, threats to security, reliability, availability, and safety for food and water resources are expected to expand.

Potential pathogens respond to changing climate and weather patterns in the context of specific biological mechanisms and environmental pathways that drive transmission. Organisms respond positively or negatively to climate and weather relative to limiting factors for their development and transmissibility to hosts. Potential new pathogen and vector introductions may further complicate predictions. Uncertainty about changing distributions for hosts, pathogens, and vectors, and their interactions heightens the immediate need for development of refined and standardized capacities for rapid identification, surveillance, and monitoring (e.g., Hoberg et al. 2008; Miller et al. 2013; Brooks et al. 2014; Beard et al. 2016). Critical host-pathogen systems likely to respond to anticipated changes in the NE include the following (see also Supplementary Material): (1) arthropods, including mosquitoes and mosquito-borne arboviruses; biting midges and Bluetongue virus; and ticks and tick-borne diseases; (2) livestock viruses, especially bovine viral diarrhea (BVD); (3) pathogenic avian influenza; (4) enteric protozoans in livestock and poultry (e.g., Giardia, Cryptosporidium, Eimeria); and (5) gastrointestinal and pulmonary nematodes of livestock and interactions between climate change and drug resistance.

Monitoring and targeted surveillance of pathogens at broad geographic scales requires development of long-term archives of data and specimens to document diversity, abundance, and infection rates in space and time (e.g., Hoberg et al. 2008; Brooks et al. 2014). Collections of geo-referenced data linked to archived specimens suitable for authoritative identification, genomebased analyses, and population genetic approaches are a requisite to developing the baselines for pathogens against which the effects on diversity, host, and geographic range may be assessed. Such data are critical to understanding how external drivers work in conjunction with climate change in determining the potential for exposure by pathogens and associated risks for emerging diseases among livestock populations and by extension, humans (Hoberg et al. 2008; Beard et al. 2016).

Overall, increased average maximum temperatures, days with temperatures exceeding $25^{\circ} \mathrm{C}$, higher annual precipitation in the Northeast, and increased atmospheric $\mathrm{CO}_{2}$ concentration are expected to either increase or decrease forage productivity depending on the crop, and may decrease protein content and forage digestibility. These changes may cause winter damage to sensitive forage species. Increased temperatures may reduce fertility in dairy cattle and heat 
stress-induced inflammation may limit energy available for productive functions. Additional loss in milk production due to decreased feed intake is estimated to be up to $1 \%$ of the projected annual milk production through 2100 . The effects of climate change on the beef industry in the Northeast are expected to be minimal and broiler production in the region may benefit from warmer winter and summer temperatures. Providing adequate housing and ventilation to offset climate changes will be important for both the broiler and layer industries and may increase the price of eggs. Climate change is expected to have an economic impact on the horse industry and increased temperatures and more intense storms will likely increase nutrient losses and gaseous emissions from animal manure. Continued animal health monitoring is necessary to address responses of host animals, pathogens, and disease vectors to climate change.

Open Access This article is distributed under the terms of the Creative Commons Attribution 4.0 International License (http://creativecommons.org/licenses/by/4.0/), which permits unrestricted use, distribution, and reproduction in any medium, provided you give appropriate credit to the original author(s) and the source, provide a link to the Creative Commons license, and indicate if changes were made.

\section{References}

AHCF (2005) The economic impact of the horse industry on the United States. The American Horse Council Foundation

APHIS (Animal and Plant Health Inspection Service) (1998) USDA National Animal Health Monitoring System. Baseline reference of 1998 equine health and management. pp 89-91

Baumgard LH, Rhoads RP (2013) Effects of heat stress on post-absorptive metabolism and energetics. Annu Rev Anim Biosci 1:311-337

Beard CB, Eisen RJ, Barker CM, Garofalo JF, Hahn M, Hayden M, Monaghan AJ, Ogden NH, Schramm PJ (2016) Chapter 5: Vectorborne diseases. The impacts of climate change on human health in the United States: a scientific assessment. U.S. Global Change Research Program, Washington, DC, pp 129-156. doi: 10.7930/J0765C7V. Accessed 19 Aug 2016

Bell DD, Weaver WD (2002) Commercial chicken meat and egg production. Springer, US

Boichard D, Brochard M (2012) New phenotypes for new breeding goals in dairy cattle. Animal 6:544-550

Bott RC, Greene EA, Koch K, Martinson KL, Siciliano PD, Williams C, Trottier NL, Burk A, Swinker A (2013) Production and environmental implications of equine grazing. J Equine Vet Sci 33:1031-1043

Brooks DR, Hoberg EP, Gardner SL, Boeger W, Galbreath KE, Herczeg D, Mejía-Madrid HH, Racz E, Tsogtsaikhan Dursahinhan A (2014) Finding them before they find us: informatics, parasites and environments in accelerating climate change. Comp Parasitol 81:155-164

Cabrera VE (2014) Economics of fertility in high-yielding dairy cows on confined TMR systems. Animal 8:211-221

Challinor AJ, Watson J, Lobell DB, Howden SM, Smith DR, Chhetri N (2014) A meta-analysis of crop yield under climate change and adaptation. Nat Clim Chang 4:287-291. doi:10.1038/NCLIMATE2153

De Rensis F, Garcia-Ispierto I, López-Gatius F (2015) Seasonal heat stress: clinical implications and hormone treatments for the fertility of dairy cows. Theriogenology 84:659-666

De Vries A (2006) Determinants of the cost of days open in dairy cattle. In: Proceedings of the 11th Symposium of the International Society for Veterinary Epidemiology and Economics. Cairns, p 1114

Dell CJ, Salon PR, Franks CD, Benham EC, Plowden Y (2008) No-till and cover crop impacts on soil carbon and associated properties on Pennsylvania dairy farms. J Soil Water Conserv 62:189-196

Dikmen S, Wang X, Ortega MS, Cole JB, Null DJ, Hansen PJ (2015) Single nucleotide polymorphisms associated with thermoregulation in lactating dairy cows exposed to heat stress. J Anim Breed Genet 132:409-419

Ebeid TA, Suzuki T, Sugiyama T (2012) High ambient temperature influences eggshell quality and calbindinD28k localization of eggshell gland and all intestinal segments of laying hens. Poult Sci 91:2282-2287

Franzluebbers AJ (2002) Water infiltration and soil structure related to organic matter and its stratification with depth. Soil Tillage Res 66:197-205

Getachew G, Putnam DH, DeBen CM, De Peters EJ (2016) Potential of sorghum as an alternative to corn forage. Am J Plant Sci. doi:10.4236/ajps.2016.77106 Accessed 19 August 2016

Hoberg EP, Polley L, Jenkins EJ, Kutz SJ (2008) Pathogens of domestic and free-ranging ungulates: global climate change in temperate to boreal latitudes across North America. Rev Off Int Epizoot 27:511-528 
Holcomb KE, Tucker CB, Stull CL (2015) Shade use by small groups of domestic horses in a hot, sunny environment. J Anim Sci 93:5455-5464

Hristov AN, Price WJ, Shafii B (2004) A meta-analysis examining the relationship among dietary factors, dry matter intake, and milk yield and milk protein yield in dairy cows. J Dairy Sci 87:2184-2196

Hudson BD (1994) Soil organic matter and available water capacity. J Soil Water Conserv 49:189-194

Johnson JS, Abuajamieh M, Sanz Fernandez MV, Seibert JT, Stoakes SK, Nteeba J, Keating AF, Ross JW, Rhoads RP, Baumgard L (2015) Thermal stress alters postabsorptive metabolism during pre- and postnatal development. In: Climate change impact on livestock: adaptation and mitigation. Springer, India. doi: 10.1007/978-81-322-2265-1_5

Kunkel KE, Stevens LE, Stevens SE, Sun L, Janssen E, Wuebbles D, Rennells J, DeGaetano A, Dobson JG (2013) Part 1. Climate of the Northeast U.S. NOAA Technical Report NESDIS 142-1, Washington, DC

Liang Y, Tabler GT, Watkins SE, Xin H, Berry IL (2009) Energy use analysis of open-curtain vs. totally enclosed broiler houses in northwest Arkansas. Appl Eng Agric 25:577-584

Lott BD, Simmons JD, May JD (1998) Air velocity and high temperature effects on broiler performance. Poult Sci 77:391-393

Lyons RK, Machen RV (2001) Stocking rate: the key grazing management decision. Texas Agric Extn Service. http://edwards.agrilife.org/files/2011/03/211.pdf. Accessed 19 Aug 2016

McDowell RE (1972) Improvement of livestock production in warm climates. W. H. Freeman \& Co., San Francisco

Miller RS, Farnsworth ML, Malmberg JL (2013) Diseases at the livestock-wildlife interface: status, challenges and opportunities in the United States. Prev Vet Med 110:119-132

Mitlöhner FM, Galyean ML, McGlone JJ (2002) Shade effects on performance, carcass traits, physiology, and behavior of heat-stressed feedlot heifers. J Anim Sci 80:2043-2050

NASS (2012) Census of agriculture, United States summary and state data. Volume 1 - Geographic Area Series Part 51 (AC-12-A-51)

Nienaber JA, Hahn GL (2007) Livestock production system management responses to thermal challenges. Int J Biometeorol 52:149-157

NRC (1981) Effect of environment on nutrient requirements of domestic animals. Natl. Acad. Sci, Washington, DC

NRC (2001) Nutrient requirements of dairy cattle, 7th rev edn. Natl. Acad. Sci, Washington, DC

NRC (2007) Nutrient requirements of horses, 6th rev edn. Natl. Acad. Sci, Washington, DC

NRC (2016) Nutrient requirements of beef cattle, 8th rev edn. Natl. Acad Sci, Washington, D.C. doi:10.17226/19014

NRCC (2016) Northeast Regional Climate Center. http://www.nrcc.cornell.edu/regional/tables/tables.html. Accessed 19 Aug 2016

Reece F, Deaton J, Vardaman T (1969) The effect of temperature exposure on broiler condemnation. Poult Sci 48:288-294. doi:10.3382/ps.0480288

Rotz CA (2004) Management to reduce nitrogen losses in animal production. J Anim Sci 82:E119-E137

Rotz CA, Kleinman PJA, Dell CJ, Veith TL, Beegle DB (2011) Environmental and economic comparisons of manure application methods in farming systems. J Environ Qual 40:438-448

Rotz CA, Montes F, Hafner SD, Heber AJ, Grant RH (2014) Ammonia emission model for whole farm evaluation of dairy production systems. J Environ Qual 43:1143-1158

Rotz CA, Skinner RH, Stoner AMK, Hayhoe K (2016) Evaluating greenhouse gas mitigation and climate change adaptation in dairy production using farm simulation. Trans ASABE (in press)

Six J, Conant RT, Paul EA, Paustian K (2002) Stabilization mechanisms of soil organic matter: implications for C-saturation of soil. Plant Soil 241:155-176

Snoeks MG, Moons CPH, Odberg FO, Aviron M, Geers R (2015) Behavior of horses on pasture in relation to weather and shelter - a field study in a temperate climate. J Vet Behav 10:561-568

Stanton, TL (1995) Damage control strategies for cattle exposed to cold stress. Symp Proc: Intake by Feedlot Cattle. OK Ag Exp Station. pp. 289-298

St-Pierre NR, Cobanov B, Schnitkey G (2003) Economic losses from heat stress by US livestock industries. J Dairy Sci 86:E52-E77

Sun L, Kunkel KE, Stevens LE, Buddenberg A, Dobson JG, Easterling DR (2015) Regional surface climate conditions in CMIP3 and CMIP5 for the United States: differences, similarities, and implications for the US national climate assessment. NOAA Technical Report NESDIS 144 doi:10.7289/V5RB72KG

Thibeault JM, Seth A (2014) Changing climate extremes in the Northeast United States: observations and projections from CMIP5. Clim Chang 127:273-287

USDA-ERS (2016) Top 5 agricultural commodities, 2014. USDA Economic Research Service. http://www.ers. usda.gov/data-products/state-fact-sheets/state-data.aspx\#P051f1f67a3f24fbab7e181a363d15ee4_2_586iT21 R0x0. Accessed 19 Aug 2016

USDA-NASS (2015) Poultry-production and value 2015 summary, ISSN: 1949-1573; http://usda.mannlib. cornell.edu/usda/current/PoulProdVa/PoulProdVa-04-28-2016.pdf 